Avalaible online: https://ejournal.iai-tribakti.ac.id/index.php/pgmi

Article doi: https://doi.org/10.33367/jiee.v2i1.1064

\title{
Upaya Meningkatkan Prestasi Belajar Siswa Pada Mata Pelajaran Aqidah Akhlak Melalui Pendekatan Contextual Teaching And Learning
}

\section{Efforts to Improve Student Learning Achievement in Aqeedah Moral Subjects Through the Contextual Teaching And Learning Approach}

\author{
Hascita Istiqomah \\ Universitas Islam Negeri Sunan Kalijaga Yogyakarta \\ hasicitaistiqomah@gmail.com
}

\begin{abstract}
This study aims to improve student achievement in Aqeedah Akhlak through the Contextual Teaching and Learning approach. This research is a class action research carried out in two cycles in the first cycle conducted 2 meetings while in the second cycle conducted 1 meeting. Each cycle consists of planning, implementing actions, observing and reflecting. Data on student learning pest obtained through student test results at the end of cycle I and cycle II, the results of learning activities are seen by racing on the guidelines for student activity observation sheets and teacher activities. The indicator of the success of this study is to improve student learning achievement in the subject of aqidah moral through the Contextual Teaching and Learning approach. Seen at an average value of 86.31 with a classical completeness percentage of 89.43\%. The application of the Contextual Teaching and Learning approach can improve student achievement in class III MI Assa'adah Labuapi District, West Lombok Regency Academic Year 2017/2018.
\end{abstract}

Keywords: Learning Achievement, Contextual Teaching and Learning (CTL).

\begin{abstract}
Abstrak
Penelitian ini bertujuan untuk meningkatkann prestasi belajar siswa pada mata pelajaran Aqidah Akhlak melalui pendekatan Contextual Teaching and Learning. Penelitian ini merupakan penelitian tindakan kelas yang di laksanakan dalam dua siklus pada siklus I dilakukan 2 pertemuan sedangkan pada siklus II dilakukan 1 pertemuan. Masingmasing siklus terdiri dari tahap perencanaan, pelaksanaan tindakan, observasi dan refleksi. Data pestasi belajar siswa di peroleh melalui hasil tes siswa pada akhir siklus I dan siklus II, hasil aktivitas kegiatan pembelajaran dilihat dengan berpacu pada pedoman lembar observasi aktivitas siswa dan aktivitas guru. Indikator keberhasilan penelitian ini yaitu meningkatkan prestasi belajar siswa pada mata pelajaran aqidah akhlak melalui pendekatan Contextual Teaching and Learning. Dilihat
\end{abstract}


pada nilai rata-rata 86,31 dengan presentase ketuntasan klasikal yaitu 89,43\%.Penerapan pendekatan Contextual Teaching and Learning dapat meningkatkan prestasi belajar siswa kelas III MI Assa'adah Kecamatan Labuapi Kabupaten Lombok Barat Tahun Ajaran $2017 / 2018$.

Kata Kunci: Prestasi Belajar, Contextual Teaching and Learning (CTL).

\section{Pendahuluan}

Pendidikan adalah suatu proses dalam rangka mempengaruhi peserta didik supaya mampu menyesuaikan diri sebaik mungkin dengan lingkungannya, dan dengan demikian akan menimbulkan perubahan dalam dirinya yang memungkinkannya untuk berfungsi dalam kehidupan masyarakat. ${ }^{1}$ Pada dasarnya pertumbuhan dan perkembangan peserta didik bergantung pada dua unsur yang saling mempengaruhi, yakni bakat yang dimiliki oleh peserta didik sejak lahir, dan lingkungan yang mempengaruhi hingga bakat itu tumbuh dan berkembang. ${ }^{2}$

Hal ini sejalan dengan tujuan pendidikan nasional yang tertuang dalam Undang-undang No 20 tahun 2003, tentang Sistem Pendidikan Nasional pasal 3 sebagai berikut: "Pendidikan Nasional bertujuan untuk berkembangnya potensi siswa agar menjadi manusia yang beriman dan bertakwa kepada Tuhan Yang Maha Esa, berakhlak mulia, sehat,

1 Oemar Hamalik, Kurikulum Dan Pembelajaran, (Jakarta: Bumi Aksara, 2013), h. 02.

2 Hamalik. berilmu, cakap, kreatif, mandiri, dan menjadi warga Negara yang demokratis serta bertanggung jawab". ${ }^{3}$

Guru dalam pelaksanaan pembelajaran harus memilih dan menentukan strategi, pendekatan, model dan metode sesuai dengan kemampuannya. Berbagai macam strategi, pendekatan, model dan metode yang digunakan di setiap proses pembelajaran akan memberikan sesuatu yang positif terhadap cara belajar siswa. Karena setiap siswa memiliki karakteristik yang berbeda-beda. Maka demikian, guru berperan penting untuk mengembangkan berbagai strategi, pendekatan, model dan metode di dalam proses pembelajaran agar pembelajaran tidak monoton dan hanya berpusat hanya pada guru.

Pendekatan dibutuhkan untuk meningkatkan prestasi belajar siswa, adapun pengertian prestasi belajar adalah hasil yang telah dicapai dari suatu kegiatan yang berupa perubahan tingkah laku yang dialami oleh subyek belajar di dalam

32Depdiknas, Undang-Undang Sistem Pendidikan (Jakarta: Direktorat Jenderal Pendidikan dan Kebudayaan, 2003) h. 3.

el Bidayah: Journal of Islamic Elementary Education Volume 2, Nomor 1, March 2020 
suatu interaksi dengan

lingkungannya. ${ }^{4}$

Guru menginginkan prestasi

belajar siswa meningkat sesuai dengan KKM yang ada pada satuan pendidikan. Dimana guru menginginkan siswa memiliki pemahaman yang mendalam terhadap materi yang diajarkan dan mampu menerapkannya dalam kehidupan sehari-hari, sehingga tujuan pembelajaran dapat tercapai sesuai dengan apa yang diinginkan. Namun, realita yang terjadi saat ini di kelas III A MI Assa'adah Labuapi masih jauh dari apa yang diharapkan, Hasil belajar siswa pada mata pelajaran aqidah akhlak masih rendah yang mengindikasikan bahwa siswa belum sepenuhmya menguasai dan memahami materi yang disampaikan oleh guru.

Terbukti dengan jumlah siswa yang mencapai Kriteria Ketuntasan Minimal (KKM) baru berjumlah 9 orang dari 19 siswa yang ada di kelas tersebut (seperti yang terlampir dalam lampiran tentang hasil MID semester genap). Artinya siswa yang mencapai KKM hanya $47 \%$. Hal ini yang menyebabkan guru harus melaksanakan pembelajaran remedial secara klasikal.
Dalam proses pembelajaran aqidah akhlak pembelajaran hanya berpusat pada guru (teacher center), sehingga siswa dalam kegiatan pembelajaran mudah bosan dan kurang memahami materi yang diajarkan. Guru belum mencoba menggunakan metode dan pendekatan yang beragam, yang jika digunakan akan membuat siswa cepat mengerti dan cepat memahami pelajaran yang diajarkan, sehingga prestasi belajar siswa secara otomatis akan meningkat.

Salah satu alternatif pemecahan masalah di atas adalah guru dapat memilih Pendekatan CTL agar dapat meningkatkan prestasi belajar siswa pada mata pelajaran aqidah akhlak. Dimana pendekatan CTL menuntut siswa menemukan sendiri materi pelajaran bukan menghafalkan, sehingga pembelajaran lebih bermakna karena siswa melakukan sendiri kegiatan yang berhubungan dengan materi yang ada. ${ }^{5}$ Jadi siswa dapat memahami materi pembelajaran dengan sendirinya dan siswa dalam proses pembelajaran menjadi semangat. Hal ini, secara otomatis

\footnotetext{
5 Sudirmanz, "componen model CTL", $\quad$ http://www,.sekolahdasar. net/2012/05/ komponen-modelcontextual-teaching-and.html" $\quad \backslash \mathrm{t}$ "_blank". Diakses pada tanggal 13-042017 pukul 01:20 WITA. 
Oleh: Hascita Istiqomah

dapat meningkatan prestasi belajar siswa

Berdasarkan uraian di atas, perlu dilakukan suatu upaya dalam meningkatkan prestasi belajar siswa dengan cara menerapkan model Pendekatan Contextual Teaching and Learning. Berdasarkan hal tersebut di atas maka peneliti terdorong untuk meneliti tentang: "Upaya Meningkatkan Prestasi Belajar Siswa Pada Mata Pelajaran Aqidah Akhlak Melalui Pendekatan Contextual Teaching And Learning (CTL) Kelas III MI Assa'adah Labuapi Tahun Ajaran 2017/2018".

\section{Metode}

Penelitian ini menggunakan penelitian tindakan kelas karena ingin menguji suatu metode pembelajaran dalam kegiatan pembelajaran dengan menerapkan pendekatan Contextual Teaching and Learning (CTL) pada pokok bahasan akhlak terpuji sebagai upaya untuk meningkatkan prestasi belajar siswa kelas III A pada mata pelajaran aqidah akhlak MI Assa'adah Kec. Labuapi Kab. Lombok Barat tahun pelajaran 2017/2018.

Sampel dalam penelitian ini sebanyak 19 siswa yang terdiri dari 8 laki-laki dan 11 perempuan. Adapun metode Pengumpulan Data Dalam penelitian ini menggunakan 4 metode pengumpulan data yang dianggap penting, yakni Observasi,
Tes, Metode Dokumentasi dan Wawancara. Sedangkan teknik analisis data dalam penelitian ini terdapat dua jenis data yaitu data kuantitatif dan data kualitatif. Data kuantitatif diperoleh dari tes hasil belajar siswa. Sedangkan data kualitatif diperoleh dari hasil pengamatan proses pembelajaran berupa aktivitas siswa dan guru melalui lembar observasi.

\section{Hasil dan Pembahasan}

Penelitian ini dilakukan dalam 2 siklus dengan subjek penelitian adalah 19 orang siswa pada kelas III A semester II MI Assa'adah Labuapi 2017/2018. Dari 19 orang siswa tersebut meliputi 8 orang laki-laki dan 11 orang perempuan. Penelitian ini dimulai pada tanggal 15 April sampai tanggal 10 Juni 2017, dengan penerapan pendekatan Contextual Teaching and Learning (CTL) pada mata pelajaran Aqidah Akhlak pada pokok bahasan Akhlak Terpuji. Selain itu ada beberapa aspek yang menjadi bahan pengamatan diantaranya meliputi perhatian siswa terhadap pelajaran, keaktifan siswa dalam bertanya, menjawab pertanyaan dan mengerjakan tugas. Berikut ini akan diuraikan deskripsi siklus I dengan 2 kali pertemuan dan siklus II dengan 1 kali pertemuan.

\section{Siklus I}

Kegiatan pembelajaran pada siklus I dilaksanakan 2 kali 
pertemuan. Pertemuan pertama dilaksanakan pada hari Sabtu tanggal 15 April 2017. Penelitian ini dilakukan pada submateri Arti rukun dan tolong menolong dan Ciriciri orang yang rukun dan tolong menolong. Pertemuan kedua dilaksanakan pada hari Sabtu tanggal 22 April 2017 dengan submateri keuntungan memiliki sifat rukun dan tolong menolong dan keuntungan memiliki sifat rukun dan tolong menolong.

a. Aktivitas Siswa

1) Pertemuan 1 siklus I

Data aktivitas belajar siswa pada siklus I pertemuan pertama selama proses pembelajaran dengan menggunakan pendekatan Contextual Teaching and Learning dapat di lihat pada (Tabel 1.1). Secara lengkap, hasil observasi aktivitas belajar siswa pada siklus I pertemuan pertama dapat dilihat pada table 1.1 dibawah ini:

Tabel.1

Hasil Observasi Aktivitas Siswa Siklus I pertemuan 1

\begin{tabular}{|c|c|c|}
\hline No & Indikator & Skor \\
\hline & $\begin{array}{l}\text { Kesiapaan siswa dalam mengikuti } \\
\text { pembelajaran }\end{array}$ & 1 \\
\hline 2 & $\begin{array}{l}\text { Antusias siswa dalam mengikuti } \\
\text { pembelajaran }\end{array}$ & 2 \\
\hline 3 & $\begin{array}{l}\text { Kerjasama siswa dalam kelompok } \\
\text { diskusi }\end{array}$ & 1 \\
\hline 4 & $\begin{array}{l}\text { Interaksi siswa dengan siswa saat } \\
\text { diskusi }\end{array}$ & 2 \\
\hline 5 & Interaksi siswa dengan guru & 1 \\
\hline 6 & $\begin{array}{l}\text { Partisipasi siswa dalam menyimpulkan } \\
\text { hasil diskusi }\end{array}$ & 1 \\
\hline \multicolumn{2}{|c|}{ Total skor } & 8 \\
\hline \multicolumn{2}{|c|}{ Persentase skor observasi } & 44,44 \\
\hline \multicolumn{2}{|c|}{ Kategori } & $\begin{array}{c}\text { Kurang } \\
\text { Aktif }\end{array}$ \\
\hline
\end{tabular}

el Bidayah: Journal of Islamic Elementary Education Volume 2, Nomor 1, March 2020
Sumber : hasil observasi aktivitas siswa kelas III A siklus 1 pertemuan 1 MI Assa'adah Labuapi.

Terlihat dari hasil Observasi aktivitas belajar siswa siklus I tersebut, terlihat bahwa total skor 8 dengan persentase 44,44 dengan kategori kurang aktif seperti terlihat pada Tabel 1.1 diatas. Oleh karena itu peneliti akan melakukan perbaikan pada siklus I pertemuan 2, kerena aktivitas peserta didik tergolong masih kurang aktif.

2) Pertemuan 2 siklus I

Data lengkap mengenai aktivitas belajar siswa pada siklus I pertemuan kedua selama proses pembelajaran dengan menerapkan pendekatan Contextual Teaching and Learning (CTL) dapat dilihat pada table 1.2. Dari data hasil observasi belajar siswa siklus I pertemuan pertama tersebut, terlihat bahwa total skor yang diperoleh adalah 8 dengan persentase 44,44 dengan kategori kurang aktif seperti terlihat pada table 1.1 diatas. Oleh karena itu peneliti melakukan perbaikan pada siklus I pertemuan kedua. Dalam pertemuan kedua ini aktivitas siswa mengalami peningkatan yang cukup baik, Hal ini terlihat pada table 1.2 dibawah ini: 
Tabel 1.2

Hasil Observasi Aktivitas Siswa Siklus I pertemuan 2

\begin{tabular}{|c|l|c|}
\hline No & \multicolumn{1}{|c|}{ Indikator } & Skor \\
\hline 1 & $\begin{array}{l}\text { Kesiapaan siswa dalam mengikuti } \\
\text { pembelajaran }\end{array}$ & 2 \\
\hline 2 & $\begin{array}{l}\text { Antusias siswa dalam mengikuti } \\
\text { pembelajaran }\end{array}$ & 2 \\
\hline 3 & $\begin{array}{l}\text { Kerjasama siswa dalam kelompok } \\
\text { diskusi }\end{array}$ & 2 \\
\hline 4 & Interaksi siswa dengan siswa saat diskusi & 2 \\
\hline 5 & Interaksi siswa dengan guru & 2 \\
\hline 6 & $\begin{array}{l}\text { Partisipasi siswa dalam menvimpulkan } \\
\text { hasil diskusi }\end{array}$ & 1 \\
\hline Total skor & 11 \\
\hline Persentase skor observasi & 61,44 \\
\hline Kategori & $\begin{array}{c}\text { Cukup } \\
\text { Aktif }\end{array}$ \\
\hline
\end{tabular}

Sumber : hasil observasi aktivitas siswa kelas III A siklus 1 pertemuan 2 MI Assa'adah Labuapi.

Terlihat dari hasil Observasi belajar siswa siklus I pertemuan 2 diatas, terlihat bahwa total skor yang di peroleh adalah 11 dengan persentase 61,44 yang berkategori cukup aktif seperti terlihat pada table 1.2 diatas. Oleh karena itu perlu diadakan perbaikan pada siklus II, kerena aktivitas belajar siswa tergolong masih cukup aktif.

b. Aktivitas guru

1) Pertemuan 1 siklus I

Data lengkap mengenai hasil observasi aktivitas guru pada siklus I pertemuan pertama selama proses pembelajaran dengan menerapkan pendekatan Contextual Teaching and Learning (CTL) dapat dilihat dalam tabel 1.3 berikut ini :
Tabel 1.3

Hasil Observasi Aktivitas Guru Siklus I pertemuan 1

\begin{tabular}{|c|l|c|}
\hline No & \multicolumn{1}{|c|}{ Indikator } & Skor \\
\hline 1 & $\begin{array}{l}\text { Persiapan sebelum kegiatan } \\
\text { pembelajaran }\end{array}$ & 2 \\
\hline 2 & $\begin{array}{l}\text { Pemberian motivasi dan apersepsi } \\
\text { kepada siswa }\end{array}$ & 1 \\
\hline 3 & Pengaturan kegiatan kelompok & 3 \\
\hline 4 & $\begin{array}{l}\text { Mebimbing siswa dalam kegiatan } \\
\text { diskusi kelompok }\end{array}$ & 2 \\
\hline 5 & $\begin{array}{l}\text { Pemberian umpan balik terhadap hasil } \\
\text { diskusi siswa }\end{array}$ & 1 \\
\hline 6 & Mengakhiri/menutup pembelajaran & 1 \\
\hline Total skor & 10 \\
\hline Persentase skor observasi & 55,56 \\
\hline Kategori & $\begin{array}{c}\text { Cukup } \\
\text { Aktif }\end{array}$ \\
\hline
\end{tabular}

Sumber : hasil observasi aktivitas guru siklus 1 pertemuan 1 MI Assa'adah Labuapi.

Dari data tersebut diatas terlihat bahwa skor yang diperoleh guru adalah 10 dengan persentase 55,56 dan tergolong dalam kategori cukup aktif, dapat dilihat pada table 1.3 diatas.

2) Pertemuan 2 siklus I

Data lengkap mengenai aktivitas guu pada siklus I pertemuan kedua selama proses pembelajaran dengan menerapkan pendekatan Contextual Teaching and Learning (CTL) dapat dilihat pada table 1.3 diatas. Dari data hasil observasi aktivitas guru siklus I pertemuan kedua tersebut, terlihat bahwa total skor yang diperoleh adalah 13 dengan persentase 72,22 dengan kategori cukup aktif seperti terlihat pada table 1.4 dibawah ini, terlihat bahwa terjadi peningkatan pada pertemuan kedua ini akan tetapi perlu diadakan perbaikan lagi 
untuk hasil yang lebih baik karena masih dalam kategori cukup aktif. Oleh karena itu peneliti melakukan perbaikan pada siklus I pertemuan kedua. Dalam pertemuan kedua ini aktivitas siswa mengalami peningkatan yang cukup baik, Hal ini terlihat pada table 1.4 dibawah ini:

Tabel 1.4

Hasil Observasi Aktivitas Guru Siklus I pertemuan 2

\begin{tabular}{|c|l|c|}
\hline No & \multicolumn{1}{|c|}{ Indikator } & Skor \\
\hline 1 & $\begin{array}{l}\text { Persiapan sebelum kegiatan } \\
\text { pembelajaran }\end{array}$ & 3 \\
\hline 2 & $\begin{array}{l}\text { Pemberian motivasi dan apersepsi } \\
\text { kepada siswa }\end{array}$ & 2 \\
\hline 3 & Pengaturan kegiatan kelompok & 3 \\
\hline 4 & $\begin{array}{l}\text { Mebimbing siswa dalam kegiatan } \\
\text { diskusi kelompok }\end{array}$ & 3 \\
\hline 5 & $\begin{array}{l}\text { Pemberian umpan balik terhadap hasil } \\
\text { diskusi siswa }\end{array}$ & 1 \\
\hline 6 & Mengakhiri/ menutup pembelajaran & 1 \\
\hline Total skor & 13 \\
\hline Persentase skor observasi & 72,22 \\
\hline Kategori & $\begin{array}{c}\text { Cukup } \\
\text { Aktif }\end{array}$ \\
\hline
\end{tabular}

Sumber : hasil observasi aktivitas guru siklus 1 pertemuan 2 MI Assa'adah Labuapi.

Terlihat dari hasil Observasi aktivitas guru siklus I pertemuan 2 diatas, terlihat bahwa total skor yang di peroleh adalah 13 dengan persentase 72,22 yang berkategori cukup aktif seperti terlihat pada table 1.4 diatas.

c. Tahap Evaluasi/Refleksi

Pengumpulan data hasil evaluasi belajar siklus I dilakukan pada tanggal 22 April 2017, dimana tes evaluasi prestasi belajar siswa kelas III A pada mata pelajaran aqidah akhlak diberikan soal pilihan ganda yang berjumlah 10 soal. Adapun hasil tes siswa dapat dilihat pada table 1.5 dan prestasi belajar siswa secara lengkap dapat di lihat pada table 1.6 dibawah ini:

Tabel 1.5

Hasil Tes Siswa Kelas III A MI Assa'adah Siklus I

\begin{tabular}{|c|c|c|c|}
\hline No & Nama siswa & Skor & Ketuntasan \\
\hline 1 & Aria Saputra & 60 & tidak tuntas \\
\hline 2 & Fitriani & 70 & Tuntas \\
\hline 3 & Hani & 60 & tidak tuntas \\
\hline 4 & Putri Widiawati & 90 & Tuntas \\
\hline 5 & M. Alfian Rizki Apriadi & 20 & tidak tuntas \\
\hline 6 & Marina Holidianti & 40 & tidak tuntas \\
\hline 7 & Julia Zulpa & 50 & tidak tuntas \\
\hline 8 & Juwita & 70 & Tuntas \\
\hline 9 & Siti Muawanah & 60 & tidak tuntas \\
\hline 10 & Muhammad Rido & 60 & tidak tuntas \\
\hline 11 & Muslimah & 70 & Tuntas \\
\hline 12 & Alia Salsabila & 70 & Tuntas \\
\hline 13 & Ilham Alfi Syahrin & 90 & Tuntas \\
\hline 14 & Kayla Ziadatul Mahabbah & 80 & Tuntas \\
\hline 15 & M. Fahrian Azwadi & 80 & Tuntas \\
\hline 16 & M. Imam Subki & 70 & Tuntas \\
\hline 17 & M. Tomi Ramadhan & 70 & Tuntas \\
\hline 18 & Nadila Widyawati Fitri & 80 & Tuntas \\
\hline 19 & Yusuf Salim Salehat & 30 & tidak tuntas \\
\hline
\end{tabular}

Sumber : hasil Tes siswa kelas III A siklus 1 MI Assa'adah Labuapi.

Tabel 1.6

Data Hasil Belajar Siswa Siklus I Kelas III A MI Assa'adah.

\begin{tabular}{|c|l|c|}
\hline No & \multicolumn{1}{|c|}{ Analisis Prestasi Belajar } & $\begin{array}{l}\text { Hasil } \\
\text { Belajar }\end{array}$ \\
\hline 1 & Jumlah siswa & 19 \\
\hline 2 & Jumlah siswa yang ikut tes & 19 \\
\hline 3 & Jumlah siswa yang tuntas secara individu & 11 \\
\hline 4 & $\begin{array}{l}\text { Jumlah siswa yang tidak tuntas secara } \\
\text { individu }\end{array}$ & 8 \\
\hline 5 & Jumlah total nilai keseluruhan & 1.220 \\
\hline 6 & Nilai rata-rata & 64,21 \\
\hline 7 & Jumlah siswa yang tuntas secara klasikal & $57,89 \%$ \\
\hline 8 & $\begin{array}{l}\text { Jumlah siswa yang tidak tuntas secara } \\
\text { klasikal }\end{array}$ & $42,10 \%$ \\
\hline 9 & \multicolumn{2}{|c|}{ Kategori } \\
\hline
\end{tabular}

Sumber : data hasil belajar siswa kelas III A siklus 1 MI Assa'adah Labuapi. 
Berdasarkan data hasil penelitian, dapat disimpulkan bahwa pelaksanaan siklus I ini belum mencapai indikator kerja dari penelitian. Dengan demikian perlu diadakan perbaikan tindakan pada siklus berikutnya yaitu siklus II.

Hasil tabel diatas dijelaskan bahwa prestasi belajar siswa pada siklus I dengan jumlah siswa yang mengikuti tes sebanyak 19 orang, hanya 11 siswa yang tuntas secara individual dan 8 siswa yang tidak tuntas dengan nilai rata-rata 64,21 dengan presentase ketuntasan secara klasikal 57,89\%. Hasil tersebut menunjukkan bahwa pembelajaran pada siklus I belum tuntas secara klasikal, karena siswa yang mendapat nilai $\geq 75$ hanya sebesar 57,89\% lebih rendah dari yang diharapkan yaitu sebesar $85 \%$. Hal ini menunjukkan bahwa semuanya belum mencapai indikator kerja dalam penelitian. Karena tindakan dianggap mencapai indikator jika aktivitas guru berada pada kategori aktif, sehingga pada siklus berikutnya perlu dilaksanakan peningkatan terhadap kekurangan yang terjadi pada siklus I.

\section{Siklus II}

Kegiatan belajar mengajar pada siklus II ini dilaksanakan pada hari kamis tanggal 11 mei 2017 pada pukul 09.40-10.55 Wita dalam alokasi waktu 2 x 35 menit di ruangan kelas III A dengann jumlah siswa yang mengikuti pembelajaran sebanyak 19 orang siswa. Adapun materi yang dibahas yaitu adab terhadap orang yang lebih tua dan lebih muda.

\section{a. Aktivitas siswa}

Data aktivitas belajar siswa pada siklus II selama proses pembelajaran dengan menggunakan pendekatan Contextual Teaching and Learning dapat di lihat pada table 1.7. Secara lengkap, hasil observasi aktivitas belajar siswa pada siklus II dapat dilihat pada table 1.7 dibawah ini:

Tabel 1.7

Hasil Observasi Aktivitas Siswa Siklus II

\begin{tabular}{|c|l|c|}
\hline No & \multicolumn{1}{|c|}{ Indikator } & Skor \\
\hline 1 & $\begin{array}{l}\text { Kesiapaan siswa dalam mengikuti } \\
\text { pembelajaran }\end{array}$ & 3 \\
\hline 2 & $\begin{array}{l}\text { Antusias siswa dalam mengikuti } \\
\text { pembelajaran }\end{array}$ & 3 \\
\hline 3 & Keriasama siswa dalam kelompok diskusi & 2 \\
\hline 4 & Interaksi siswa dengan siswa saat diskusi & 2 \\
\hline 5 & Interaksi siswa dengan guru & 2 \\
\hline 6 & $\begin{array}{l}\text { Partisipasi siswa dalam menyimpulkan hasil } \\
\text { diskusi }\end{array}$ & 3 \\
\hline Total skor & 15 \\
\hline Persentase skor observasi & Aktif \\
\hline Kategori & \\
\hline
\end{tabular}

Sumber : hasil observasi aktivitas siswa kelas III A siklus 2 MI Assa'adah Labuapi.

Berdasarkan tabel diatas terlihat bahwa total skor aktivitas siswa yaitu 16 dengan persentase 83,33 dan berkategori aktif. Jadi dapat dikatakan bahwa aktivitas belajar siswa pada siklus II ini meningkat yaitu dari $61,44 \%$ pada siklus I meningkat menjadi 83,33\% pada siklus II dan yang berkatagori cukup aktif menjadi berkatagori 
aktif. Tabel tentang hasil analisis observasi aktivitas siswa diatas menunjukkan bahwa aktivitas siswa dalam mengikuti pembelajaran mengalami peningkatan yang cukup signifikan, apabila proses pembelajaran sudah baik maka akan berdampak pada prestasi belajar yang baik pula.

b. Aktivitas guru

Data lengkap mengenai hasil observasi aktivitas guru pada siklus II selama proses pembelajaran dengan menerapkan pendekatan Contextual Teaching and Learning (CTL) dapat dilihat dalam tabel 1.8 berikut ini :

Tabel 1.8

Hasil Observasi Aktivitas Guru Siklus Il

\begin{tabular}{|c|l|c|}
\hline No & \multicolumn{1}{|c|}{ Indikator } & Skor \\
\hline 1 & Persiapan sebelum kegiatan pembelajaran & 3 \\
\hline 2 & Pemberian motivasi dan apersepsi kepada siswa & 3 \\
\hline 3 & Pengaturan kegiatan kelompok & 3 \\
\hline 4 & $\begin{array}{l}\text { Mebimbing siswa dalam kegiatan diskusi } \\
\text { kelompok }\end{array}$ & 2 \\
\hline 5 & $\begin{array}{l}\text { Pemberian umpan balik terhadap hasil diskusi } \\
\text { siswa }\end{array}$ & 3 \\
\hline 6 & Mengakhiri/menutup pembelajaran & 3 \\
\hline Total skor & 17 \\
\hline Persentase skor observasi & 94,44 \\
\hline
\end{tabular}

Sumber : hasil observasi aktivitas siswa guru siklus 2 MI Assa'adah Labuapi.

Dari tabel tersebut, terlihat bahwa skor yang diperoleh guru adalah 17 yang hampir mendekati 18 skor maksimal yang dapat diperoleh, dan tergolong dalam kategori aktif. Guru aktif membimbing siswa sehingga terciptanya intraksi didalam pembelajaran serta mengatur intraksi antar siswa dengan membentuk kelompok dengan baik. Hal ini juga telah mencapai indikator kerja dari penelitian, sehingga tidak perlu dilakukan perbaikan.

c. Tahap Evaluasi/Refleksi

Pengumpulan data hasil evaluasi belajar siklus I dilakukan pada tanggal 22 April 2017, dimana tes evaluasi prestasi belajar siswa kelas III A pada mata pelajaran aqidah akhlak diberikan soal pilihan ganda yang berjumlah 10 soal. Adapun hasil tes siswa pada siklus II dapat dilihat pada table 1.9 dan prestasi belajar siswa pada siklus II dapat dilihat pada table 1.10 dibawah ini:

Tabel 1.9

Hasil Tes Siswa Kelas III A MI Assa'adah Siklus II

\begin{tabular}{|c|l|c|c|}
\hline No & \multicolumn{1}{|c|}{ Nama siswa } & Skor & Ketuntasan \\
\hline 1 & Aria Saputra & 70 & Tidak Tuntas \\
\hline 2 & Fitriani & 90 & Tuntas \\
\hline 3 & Hani & 80 & Tuntas \\
\hline 4 & Putri Widiawati & 90 & Tuntas \\
\hline 5 & M. Alfian Rizki Apriadi & 80 & Tuntas \\
\hline 6 & Marina Holidianti & 90 & Tuntas \\
\hline 7 & Julia Zulpa & 80 & Tuntas \\
\hline 8 & Juwita & 90 & Tuntas \\
\hline 9 & Siti Muawanah & 80 & Tuntas \\
\hline 10 & Muhammad Rido & 80 & Tuntas \\
\hline 11 & Muslimah & 90 & Tuntas \\
\hline 12 & Alia Salsabila & 90 & Tuntas \\
\hline 13 & Ilham Alfi Syahrin & 90 & Tuntas \\
\hline 14 & Kayla Ziadatul Mahabbah & 100 & Tuntas \\
\hline 15 & M. Fahrian Azwadi & 90 & Tuntas \\
\hline 16 & M. Imam Subki & 80 & Tuntas \\
\hline 17 & M. Tomi Ramadhan & 100 & Tuntas \\
\hline 18 & Nadila Widyawati Fitri & 90 & Tuntas \\
\hline 19 & Yusuf Salim Salehat & 70 & Tidak Tuntas \\
\hline
\end{tabular}

Sumber : hasil tes belajar siswa kelas III A siklus 2 MI Assa'adah Labuapi. 
Tabel 1.10

Data Hasil Belajar Siswa Siklus II Kelas III A Mata Pelajaan Aqidah Akhlak Tahun Pelajaran 2016/2017

\begin{tabular}{|c|l|c|}
\hline$N_{0}$ & \multicolumn{1}{|c|}{ Analisis Prestasi Belajar } & Prestasi Belajar \\
\hline 1 & Jumlah siswa & 19 \\
\hline 2 & Jumlah siswa yang ikut tes & 19 \\
\hline 3 & Jumlah siswa yang tuntas secara individu & 17 \\
\hline 4 & $\begin{array}{l}\text { Jumlah siswa yang tidak tuntas secara } \\
\text { individu }\end{array}$ & 2 \\
\hline 5 & Jumlah total nilai keseluruhan & 1,640 \\
\hline 6 & Nilai rata-rata & 86,41 \\
\hline 7 & Jumlah siswa yang tuntas secara klasikal & $89,43 \%$ \\
\hline 8 & $\begin{array}{l}\text { Jumlah siswa yang tidak tuntas secara } \\
\text { klasikal }\end{array}$ & $10,52 \%$ \\
\hline 9 & \multicolumn{2}{|c|}{ Kategori } \\
\hline
\end{tabular}

Sumber : data hasil belajar siswa kelas III A siklus 2 MI Assa'adah Labuapi.

Berdasarkan data hasil penelitian, dapat disimpulkan bahwa pelaksanaan siklus II ini telah mencapai indikator kerja dari penelitian. Hasil yang dicapai pada siklus II menunjukkan bahwa persentase prestasi siswa meningkat dan bisa disimpulkan bahwa prestasi belajar siswa pada mata pelajaran Aqidah akhlak meningkat pula secara segnifikan karena siklus II ini telah mencapai target yang diharapkan, sehingga tidak perlu dilanjutkan ke siklus III.

\section{Refleksi}

Penelitian ini dilaksanakan selama kurang lebih 2 bulan, yaitu dari tanggal 15 April sampai dengan 10 Juni. Penelitian ini dilaksanakan dalam II siklus yaitu siklus I dilaksanakan dalam 2 kali pertemuan, dengan tes evaluasi dilakukan pada pertemuan ke-2.
Dari hasil observasi diperoleh data kualitatif yang akan memberikan gambaran tentang kegiatan yang dilakukan oleh guru dan siswa selama proses belajar mengajar, dan data kuantitatif diperoleh dari hasil tes belajar siswa yang berupa nilai rata-rata dan persentase dari hasil belajar siswa.

Berdasarkan hasil persentase observasi dan evaluasi yang dilakukan pada siklus I, rata-rata prestasi belajar dan aktivitas belajar siswa sudah tergolong cukup aktif yaitu dengan rata-rata prestasi belajar siswa 64,21 dan aktivitas belajar siswa yaitu 61,44 dari 1 kali pertemuan pada siklus I, aktivitas siswa masih kurang nampak, karena kurangnya penguasaan kelas oleh guru sehingga skor aktivitasnya tergolong masih cukup aktif. Dengan penerapan pendekatan Contextual Teaching and Learning (CTL), khususnya di kelas III A MI Assa'adah Labuapi, dimana siswa ikut terlibat secara langsung di dalam proses pembelajaran. Pendekatan Contextual Teaching and Learning (CTL) adalah pembelajaran yang menekankan kepada peserta didik harus lebih aktif dan mampu mengingat lebih lama, karena dimana dalam pendekatan ini guru harus mengaitkan pembelajaran dengan kehidupan sehari-hari siswa jadi siswa akan lebih mudah memahami dan mengingatnya. 
Tahap yang dilalui oleh guru dengan belajar menggunakan pendekatan Contextual Teaching and Learning (CTL) yaitu sebagaimana telah dipaparkan pada bagian sebelumnya, terdiri dari kegiatan awal, kegiatan inti dan kegiatan akhir (penutup).

Pada tahap kegiatan awal, guru melakukan apersepsi (meningkatkan kembali) pengetahuan siswa terhadap pelajaran sebelumnya, atau juga menggali kamampuan awal siswa. Tahapan berikutnya adalah memberikan kepada siswa untuk menemukan sendiri konsep bagaimana cara belajar hidup rukun dan tolong menolong dengan mencontohkan dan mengaitkan pelajaran dengan kehidupan seharihari siswa. Dengan teknik tersebut, pada kegiatan belajar siswa sehingga ada aktivitas siswa yang tidak mendengarkan, mencatat apa yang di berikan oleh guru, Begitu juga dengan aktivitas guru dalam pembelajaran tergolong dalam kategori cukup aktif dengan persentase 55,56. Namun masih terdapat kekurangan-kekurangan dimana kekurangan itu ada yang berasal dari guru dan ada yang berasal dari siswa.

Pada siklus I, aktivitas siswa dalam pembelajaran yang masih kurang walaupun sudah tergolong cukup aktif tetap juga mempengaruhi prestasi belajar. Hal ini disebabkan oleh sebagian siswa yang tidak memperhatikan penjelasan guru pada saat menyampaikan materi, masih kurang intraksi antara siswa dengan siswa lain, intraksi guru dengan siswa masih kurang sehingga aktivitas siswa masih kurang. Walaupun intraksi masih tergolong cukup aktif akan tetapi aktivitas siswa tidak menoton lagi walaupun masi kurang. Ini di sebabkan karena siswa kebanyakan bermain, di saat guru menyuruh siswa, siswa masih malu-malu untuk maju didepan kelas, pada saat giliran maju didepan kelas untuk memaparkan hasil kerja kelompoknya. Sedangkan rata-rata nilai prestasi belajar siswa yang diperoleh adalah 64,21 dan ketuntasan secara klasikal 57,89\%.

Dari hasil evaluasi pada pelaksanaan tindakan siklus II yang dilakukan diperoleh bahwa terjadi peningkatan peroses pembelajaran terhadap siswa maupun guru. Hal ini terlihat dari hasil observasi terhadap kegiatan guru dan siswa yang sudah termasuk kategori aktif. Bagi siswa yakni dapat meningkatkan kreativitas siswa dalam proses pembelajaran, dimana dapat terlihat pada kerjasama siswa dalam berdiskusi menyelesaikan dan mempresentasikan tugasnya. Selain itu siswa semakin berani bertanya kepada guru tentang apa yang belum 
Oleh: Hascita Istiqomah

dipahami, siswa juga juga semakin termotivasi untuk belajar dan menyelesaikan tugas dengan baik.

Pada tindakan siklus II, pendekatan Contextual Teaching and Learning (CTL) kembali dilaksanakan. Berdasarkan hasil observasi pada tindakan siklus II, kegiatan guru dalam melaksanakan proses pembelajaran telah meningkat. Kekurangan yang terjadi pada siklus I sudah dapat diperbaiki. siswa sudah lebih memperhatikan penjelasan guru sehingga siswa sudah bisa mengajukan pertanyaan yang belum dipahami tentang materi yang diajarkan.

Peningkatan tersebut disebabkan oleh beberapa faktor yaitu siswa berusaha memperhatikan penjelasan guru, siswa berusaha menjawab setiap pertanyaan yang diberikan oleh guru, siswa yang kurang bisa bertanya kepada siswa yang lebih bisa, siswa yang di suruh maju berusaha untuk memaparkan hasil diskusi mereka. Kerjasama antar kelompok diskusi sudah tercipta sehingga terjadi interaksi antara siswa dengan siswa. Hal ini juga tidak terlepas dari aktivitas guru yang sudah mampu memperbaiki kekurangannya pada siklus I. Pada siklus II ini juga terjadi peningkatan pada persentase aktivitas guru yaitu 88,88\% yang tergolong kategori aktif. Guru aktif membimbing siswa sehingga terciptanya intraksi didalam pembelajaran serta mengatur intraksi antar siswa dengan membentuk kelompok diskusi dengan baik, dan skor ratarata aktivitas siswa dan guru pada tindakan siklus II ini, sudah mencapai indikator keberhasilan penelitian yang telah ditetapkan maka penelitian ini tidak dilanjutkan dan berhenti pada siklus II.

Hasil pembelajaran siklus II lebih baik jika dibandingkan dengan hasil pembelajaran siklus I. Pada siklus II, siswa yang Tuntas berjumlah 15 orang sedangkan pada siklus satu hanya 11 orang, persentase aktivitas belajar siswa yang diproleh telah berada pada kategori aktif dengan nilai meningkat menjadi $83,33 \%$ dari yang sebelumnya hanya $61,44 \%$, sedangkan rata-rata nilai prestasi belajar siswa yang diperoleh adalah 86,31 dari yang sebelumnya hanya 64,21 , dengan jumlah siswa yang mengikuti tes 19 siswa dan melihat rata-rata hasil belajar siswa secara klasikal meningkat. Keaktifan siswa selama proses belajar mengajar berlangsung membantu dalam pencapaian prestasi belajar siswa.

\section{Kesimpulan}

Dari hasil penelitian dan pembahasan dapat disimpulkan bahwa penggunaan pendekatan Contextual Teavhing and Learning 
(CTL) dapat meningkatkan prestasi belajar siswa pada mata pelajaran Aqidah Akhlak kelas III MI Assa'adah Kecamatan Labuapi Kabupaten Lombok Barat tahun pelajaran 2016/2017. Hasil penelitian menunjukkan bahwa prestasi belajar siswa meningkat secara signifikan dapat dilihat pada siklus I prestasi belajar siswa yang terdiri dari 19 jumlah siswa terdapat 11 siswa berhasil mencapai nilai $\geq 75$ dengan presentase ketuntasan klasikal $57,89 \%$ dan rata-rata prestasi belajar adalah 64,21. Sementara pada siklus II diperoleh 15 siswa memperoleh nilai $\geq 75$ dengan persentase ketuntasan $89,43 \%$ dan rata-rata prestasi belajar 86,31. Hasil observasi juga menunjukkan aktivitas siswa dan guru mengalami peningkatan dari siklus I ke siklus II, pada siklus I dihasilkan persentase nilai aktivitas siswa adalah $61,44 \%$ dan mengalami peningkatan pada siklus II dengan persentase nilai $77,78 \%$ dan juga hasil observasi guru pada siklus I berkategori cukup aktif dengan persentase nilai $72,22 \%$, pada siklus II meningkat menjadi kategori aktif dengan persentase nilai $88,88 \%$.

\section{Daftar Pustaka}

Oemar Hamalik, Kurikulum Dan Pembelajaran, Jakarta: Bumi Aksara, 2013
Depdiknas, Undang-Undang Sistem Pendidikan, Jakarta: Direktorat Jenderal Pendidikan dan Kebudayaan, 2003.

Muhammad Fathurrahman Dan Sulistyorini, Belajar Dan Pembelajaran, Yogyakarta: Teras, 2012.

Sudirmanz, "componen model CTL", http://www,.sekolahdasar. net/2012/05/komponen-modelcontextual-teaching-and.html" $\backslash \mathrm{t}$ "_blank". Diakses pada tanggal 13-04-2017 pukul 01:20 WITA.

Hamdani, Strategi Belajar Mengajar, Bandung: CV Pustaka Setia, 2011.

Hariezt Ahmad "tujuan dan ruang lingkup Aqidah Akhlak MI http://www.abdimadrasah.com /2014/04/tujuan-dan-ruanglingkup-mata-pelajaran-aqidahakhlak-mi.html?m=1 Diakses pada tanggal 04 juni 2017 pukul 01:15 WITA

Jumanta Hamdayama, Model Dan Metode Pembelajaran Kreatif Dan Berkarakter, Bogor: Ghalia Indonesia, 2014.

Jamil Suprihatiningrum, Strategi Pembelajaran, Jogjakarta: ARRuzz Media, 2013

Wina Sanjaya, Strategi Pembelajaran Berorientasi Standar Proses Pendidikan, Jakarta: Kencana, 2006. 
Upaya Meningkatkan Hasil Belajar Siswa Pada Mata Pelajaran Aqidah Akhlak,Melalui Pendekatan Contextual Teaching And Learning

Oleh: Hascita Istiqomah

Rudi Hartono, Ragam Model Belajar yang Mudah diterima Murid, Jogjakarta: Diva Press, 2014. 